\title{
ANALISIS ASAM LEMAK EKSTRAK N-HEKSAN BUAH LIBO (FICUS VARIEGATA BLUME)
}

\author{
Diana Ntowe, Agung Rahmadani, Aditya Fridayanti, Rolan Rusli* \\ Laboratorium Penelitian dan Pengembangan FARMAKA TROPIS Fakultas Farmasi \\ Universitas Mulawarman, Samarinda, Kalimantan Timur \\ *Email: rolan@farmasi.unmul.ac.id
}

\begin{abstract}
ABSTRAK
Libo (Ficus varieagata Blume) merupakan tumbuhan liar yang belum termanfaatkan dalam bentuk apapun, termasuk secara tradisional karena tumbuhan ini memiliki latex pada buah dan kulit batangnya dan jika latex tersebut mengenai kulit menimbulkan gatal-gatal bahkan terjadi iritasi. Simplisia buah libo diekstraksi dengan pelarut n-heksan. Hasil ekstraksi kemudian ditambahkan dengan $\mathrm{NaOH} \mathrm{1 \%} \mathrm{dan} \mathrm{dilanjutkan} \mathrm{dengan} \mathrm{HCl} 5 \%$ untuk menghasilkan asam lemak dari buah libo. Asam lemak diekstraksi dengan kloroform. Analisis kandungan asam lemak pada ekstrak dilakukan melalui penetapan angka asam, angka penyabunan, dan angka peroksida diperoleh berturut-turut sebesar $8,79 \mathrm{mg} / \mathrm{g} \mathrm{KOH}$, $2,8 \mathrm{mg} / \mathrm{gKOH}$,dan $312 \mathrm{mgO}_{2} / \mathrm{g}$.
\end{abstract}

Kata Kunci: Libo, asam lemak, angka asam, angka penyabunan, dan angka peroksida

\begin{abstract}
Libo (Ficus variegate Blume) is a wild plant that has not been utilized in any form, including traditionally because this plant has latex on the fruit and cortex and can causing itching even irritation on skin contact. Libo fruit was extracted with n-hexane solvent. Extract was added $\mathrm{NaOH} 1 \%$ and continued with $\mathrm{HCl} 5 \%$ to obtain fatty acids. Fatty acids wereextracted with chloroform. Analysis of fatty acids content ie determination of the acid value, saponification value, and peroxide value, was respectively $8.79 \mathrm{mg} / \mathrm{gKOH}, 2.8$ $\mathrm{mg} / \mathrm{gKOH}$, and $312 \mathrm{mgO}_{2} / \mathrm{g}$.
\end{abstract}

Keywords: Libo, fatty acids, acid value, saponification value, peroxide value

\section{PENDAHULUAN}

Pada dasarnya, lemak dan minyak dihasilkan oleh alam yang bersumber dari hewan dan tanaman. Sedangkan berdasarkan pada sumbernya, minyak dan lemak dapat diklasifikasikan atas hewan (minyak hewani) dan tumbuhan (minyak nabati).

Ada beberapa sifat fisik dari minyak dan lemak yang dapat dilihat dari minyak dan lemak, antara lain: warna, bau amis, odor dan flavor, kelarutan, titik cair dan polymerism, titik didih, splitting point, titik lunak, shot melting point, berat jenis, indeks bias dan kekeruhan.

Lemak dan minyak merupakan salah satu kelompok yang termasuk golongan lipida. Satu sifat yang khas dan mencirikan golongan lipida adalah mudah larut dalam pelarut organik seperti eter, benzena, kloroform dan tidak larut dalam air. Lemak dan 
minyak secara kimia adalah trigliserida yang merupakan bagian terbesar dari kelompok lipida (Wardani, 2007).

Lemak dan minyak terdiri dari trigliserida campuran yang merupakan ester dari gliserol dan asam lemak (Ketaren, 1986). Gliserida dalam minyak dan lemak bukan merupakan gliserida sederhana, tetapi merupakan gliserida campuran yaitu molekul gliserol berikatan dengan asam lemak yang berbeda (Fessenden dan Fessenden, 1982)

Libo (Ficus varieagata Blume) merupakan tumbuhan liar yang belum termanfaatkan dalam bentuk apapun, termasuk secara tradisional karena tumbuhan ini memiliki latex pada buah dan kulit batangnya dan jika latex tersebut mengenai kulit menimbulkan gatal-gatal bahkan terjadi iritasi. Latex pada buah Libo akan dianalisis karena kemungkinan adanya asam lemak yang terkandung dalam getah atau latex buah tersebut yag diekstrak dengan pelaut n-heksan. Lalu dilakukan analisis asam lemak dengan penentuan angka asam, angka peroksida dan angka penyabunan.

\section{METODE PENELITIAN}

\section{Bahan}

Ekstrak n-heksan buah libo, $\mathrm{NaOH} 1 \%, \mathrm{HCl} 5 \%$, kloroform, $\mathrm{KOH}$ alkoholis $0,5 \mathrm{M}, \mathrm{KOH}$ $0,8 \mathrm{M}$, etanol $96 \%$, asam asetat glasial, indikator PP $1 \%$, indikator amilum $1 \%$, indikator

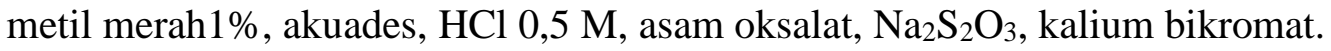

\section{Peralatan}

Seperangkat alat gelas di laboratorium

\section{Prosedur}

Persiapan sampel : Simplisia buah Libo (Ficus variegata Blume) diekstrak dengan pelarut n-heksan, ekstrak yang kering ditambahkan $\mathrm{NaOH} 1 \%$ hingga ekstrak larut sempurna dan air sebanyak $100 \mathrm{ml}$, setelah itu ditambahakan $\mathrm{HCl} 5 \%$ sebanyak penambahan $\mathrm{NaOH} 1 \%$. Penambahan kloroform sebanyak $250 \mathrm{ml}$ hingga terbentuk dua lapisan, karena sama lemak mudah terlarut dalam pelarut non polar lalu diambil lapisan bawahnya dan diuapkan hingga pelaut menguap semua.

Analisis asam lemak dalam sampel dengan penentuan angka penyabunan, angka asam dan angka peroksida.

- $\quad$ Penentuan angka peroksida. Ke dalam erlenmeyer $30 \mathrm{~mL}$ dicampurkan asam asetat glasial dan kloroform (2:3), kemudian sampel ekstrak $1 \mathrm{~g}$ dimasukkan ke dalam larutan tersebut. Selanjutnya ditambahkan padatan KI 0,5 gram dan dikocok sampai jernih. Setelah 2 menit dari penambahan KI ditambah $10 \mathrm{~mL}$ akuades. Iod yang dibebaskan dititrasi dengan thiosulfat $0,01 \mathrm{M}$. Pengerjaan blanko dengan cara yang sama hanya tidak menggunakan sampel.

- Penentuan angka asam. Sampel ekstrak $1 \mathrm{~g}$ dimasukkan ke dalam erlenmeyer, ditambahkan $10 \mathrm{~mL}$ alkohol 90\%, ditutup dan dipanaskan sampai mendidih dan digojok kuat-kuat. Kemudian didinginkan, ditambah 3 tetes pp 1\%, dititrasi dengan $\mathrm{KOH} 0,05 \mathrm{~N}$ sampai terbentuk warna merah muda yang tetap.

- $\quad$ Penentuang angka penyabunan. Sebanyak 1 gram ekstrak dimasukkan kedalam erlenmeyer ditambahkan $\mathrm{KOH}$ alkoholis. Dipanaskan hingga mendidih dn didinginkan lalu ditambahkan 3 tetes inditator pp lalu dititrasi dengan $\mathrm{HCl}$ 0,5 $\mathrm{M}$. Dihitung kadar angka penyabunan pada sampel. Pengerjaan blanko dengan cara yang sama hanya tidak menggunakan sampel. 


\section{HASIL DAN PEMBAHASAN}

\section{Preparasi sampel}

Ekstrak n-heksan buah libo petama-tama dilarutkan dengan $\mathrm{NaOH} 1 \%$ yang berfungsi untuk menghidrolisis asam lemak dan menggaramkan senyawa asam lemak, selanjutnya ditambahkan air sehingga asam lemak yang telah terbentuk menjadi garam lebih mudah ditarik oleh air karena akan lebih sulit memutuskan ikatan jika dalam bentuk garam. Penambahan $\mathrm{HCl}$ 5\% selanjutnya bertujuan untuk memustuskan ikatan asam lemak dengan air sehingga asam lemak kembali bebas dan lebih mudah ditarik dengan pelarut non polar. Untuk menarik asam lemak tersebut ditambahkan kloroform yang merupakan pelarut non polar sehingga mudah mengikat atau menarik asam lemak, sehingga terbentuk dua lapisan dimana bagian bawah merupakan kloroform yang mengikat asam lemak dan bagian atas adalah air. Bagian bawah yang diambil lalu diuapkan hingga kering, sehingga diperoleh sampel yang siap dianalisis asam lemak dengan penentuan angka asam, angka penyabunan, dan angka peroksida.

\section{Analisis Asam Lemak pada Sampel}

Angka asam adalah bilangan yang menyatakan banyaknya asam lemak bebas yang ada pada sampel. Besarnya bilangan asam tergantung dari kemurnian dan umur dari sampel tersebut. Angka penyabunan adalah bilangan yang menyatakan jumlah $\mathrm{KOH}$ atau basa yang dibutuhkan untuk mengikat asam lemak bebas yang ada dalam sampel dapat mempercepat proses oksidasi lemak karena oksidasi bebas dapat berlangsung secara enzimatis maupun non enzimatis. Senyawa peroksida merupaka produk yang terbentuk pada awal proses oksidasi lemak. Proses penentuan angka asam, angka penyabunan dan angka peroksida menggunakan larutan yang sudah tersatandarisasi.

Rumus yang digunakan untuk analisis asam lemak yaitu

- Angka Asam $\underline{\mathrm{ml} . \mathrm{KOH} \times \mathrm{M} \mathrm{KOH} \times \mathrm{BM} \mathrm{KOH}}$

$$
\text { W. sampel (gram) }
$$

- $\quad$ Angka Peroksida $(\mathrm{Vs}-\mathrm{Vb}) \times \mathrm{MNa}_{2} \mathrm{~S}_{2} \mathrm{O}_{3} \times 1000 \times 8$

W sampel (gram)

- $\quad$ Angka Penyabunan

$(\mathrm{Vs}-\mathrm{Vb}) \times \mathrm{N} \mathrm{HCl} \times \mathrm{BM} \mathrm{KOH}$

Bobot sampel (gram)

Berdasarkan analisis angka asam, angka penyabunan, dan angka peroksida diperoleh berturut-turut sebesar $8,79 \mathrm{mg} / \mathrm{g} \mathrm{KOH}, 2,8 \mathrm{mg} / \mathrm{gKOH}$,dan $312 \mathrm{mgO} / \mathrm{g}$.

\section{KESIMPULAN}

Dapat disimpulkan bahwa terdapat asam lemak dalam sampel ekstrak n-heksan buah Libo (Ficus variegata).

\section{SARAN}

Perlu dilakukan uji lanjutan yaitu analisis GC-MS untuk menegetahui jenis-jenis asam lemak dan jumlah yang terkandung dalam sampel ekstrak tersebut. 


\section{DAFTAR PUSTAKA}

1. Wardani, I. E., 2007. Uji Kualitas VCO Berdasarkan Cara Pembuatan Dari Porses Pengadukan Tanpa Pemancingan dan Proses Pengadukan dengan Pemancingan [Skripsi]. FMIPA UNES. Semarang.

2. Ketaren, S., 1986. Pengantar Teknologi Minyak dan Lemak Pangan. UI Press. Jakarta

3. Fessenden R. J. dan Joan S. F. 1986. Kimia Organik Edisi Ketiga. Penerjemah: Aloysius Hadyana Pudjaatmaka. Erlangga. Jakarta.

4. Aminah, Siti. 2010. Bilangan Peroksida Minyak Goreng Curah dan Sifat Organoleptik Tempe pada Pengulangan Penggorengan. Jurnal Pangan dan Gizi Vol. 1(1).

5. Poedjaji, A.1994. Dasar-Dasar Biokimia. UTP. Jakarta

6. Roth, H.J dam Goft Fried B. 1998. Analisis Farmasi. UGM Press. Yogyakarta 